Norris, J. R. \& Watson, D. H. (1960). J. gen. Microbiol. 22, 744-749

\title{
An Electron Microscope Study of Sporulation and Protein Crystal Formation in Bacillus cereus var. alesti
}

\author{
BY J. R. NORRIS \\ Department of Bacteriology, University of Glasgow \\ AND D. H. WATSON \\ Department of Chemistry, University of Glasgow
}

\begin{abstract}
SUMMARY: Ultra-thin sectioning techniques showed that spores and crystals were formed together in vegetative $B$. cereus var. alesti, and that the crystals developed in close proximity to nuclear elements. The exosporium which surrounds the mature spore is not a remnant of the vegetative cell wall, which disintegrates, but arises as a discrete membrane within the cell and does not, at any stage, enclose the crystal. Carbon replicas confirmed what has hitherto been only speculationnamely, that the periodicity seen on the crystal is a true feature of the surface topography. Resolution in two dimensions was occasionally possible and its implications with regard to crystal structure are discussed.
\end{abstract}

In 1953, Hannay directed attention to an aerobic spore-forming bacterium Bacillus thuringiensis, and particularly to the crystalline inclusion bodies which formed within the cells of this organism at sporulation and which had been noted by Berliner (1915) and by Mattes (1927). Hannay (1953) and Hannay \& Fitz-James (1955) carried out a thorough investigation of these crystalline bodies and showed that they were protein in nature. B. thuringiensis is an insect pathogen causing paralysis and septicaemia in the larvae of various Lepidoptera; a number of similar insect pathogens have also been shown to produce protein crystals (Steinhaus, 1954; Toumanoff, 1955). Heimpel \& Angus (1958) considered that all these organisms are varieties of the parent species $B$. thuringiensis; but other workers, recognizing the close similarity between the crystal-formers and the common aerobic spore-former B. cereus, prefer to consider the various insect pathogens as varieties of the latter organism (Young, 1958). For our part, we favour Young's nomenclature, so the strain used in the investigation reported here will be referred to as $B$. cereus var. alesti. This organism was isolated from diseased silkworms by Toumanoff \& Vago (1951) and shown to produce crystals by Steinhaus (1954). With $B$. sotto, a crystal-producing organism of Japanese origin, Angus (1954, 1956) showed that the crystal protein was toxic for susceptible lepidopterous larvae, causing paralysis when taken by mouth; similar observations were made with a Czechoslovakian strain by Vankova (1957).

\section{METHODS}

Organism. A culture of Bacillus cereus var. alesti was provided by Dr C. L. Hannay (University of Western Ontario, Canada). 
Cultures for carbon replicas. Roux bottles containing Oxoid Lab.-Lemco agar $(200 \mathrm{ml}$.) were inoculated with $1 \mathrm{ml}$. of an overnight nutrient broth culture of $B$. cereus var. alesti and incubated at $30^{\circ}$ for 10 days. By this time sporulation and crystal formation were complete and the remnants of the sporangia had disintegrated, liberating spores and crystals. The spore + crystal mixtures were harvested into sterile distilled water and washed at least 6 times by centrifugation.

Cultures for ultra-thin sectioning. The processes of harvesting and washing are likely to remove remnants of disintegrating cell wall, so giving an inaccurate picture of the cells during sporulation. Surface colonies on agar, however, can be embedded and sectioned intact, so overcoming this difficulty. Oxoid Lab.Lemco agar in Petri dishes was streaked with an overnight broth culture of Bacillus cereus var alesti and incubated at $30^{\circ}$ until well-developed colonies were formed, the centres of which showed largely free-lying spores and crystals when examined microscopically $(16-20 \mathrm{hr}$.). Blocks of agar bearing single colonies were then cut from the plate and transferred to fixative. Later it was suspected that the agar was interfering with the embedding process and colonies were grown on the surface of sterile membranes instead of directly on the agar. Oxoid cellulose acetate filter-membranes were sterilized by autoclaving them between sheets of filter-paper and placed on the surface of Lab.-Lemco agar plates. Overnight broth cultures of $B$. cereus var. alesti were streaked on to the surface of the membranes and the cultures incubated at $30^{\circ}$. Suitable colonies were formed in 16-20 hr., as with the agar cultures, and areas of membrane bearing single colonies were then cut out and transferred to fixative.

Electron microscopy; carbon replicas. The method used resembled that described by Bradley \& Williams (1957). Suspensions containing crystals and spores were allowed to dry on glass slides, shadowcast with palladium, and covered with a thin film of carbon produced by evaporation from a carbon arc. The resulting palladium-carbon films were stripped from the slides by flotation on water and mounted on specimen grids. The material was extracted from the replicas by using the potassium permanganate + potassium dichromate + concentrated sulphuric acid mixture described by Bradley \& Williams. Specimens prepared by this method were not completely satisfactory because of the inherent granularity of palladium shadowcast layers, which was exaggerated by the harsh extraction medium.

Other shadowcasting metals do not permit stripping of the carbon film from glass and the method was modified considerably to allow the use of other shadowing metals. Suspensions were freeze-dried on to formvarcovered specimen mounts to avoid possible deformation of the crystals by air-drying. The specimens were then shadowed and covered with a carbon film as before. Exposure to the reflux vapour of ethylene dichloride removed the formvar substrate within $30 \mathrm{sec}$. The material could then be extracted with $2 \%(w / v)$ sodium hydroxide solution which, although it dissolved few spores, satisfactorily removed the crystals.

Uranium shadowing was found to give less grain than palladium but was adversely affected by the alkaline extraction medium. (Sodium carbonate 
solution which did not affect the shadowcast layer was not an efficient extraction agent, although Hannay \& Fitz-James (1955) report that the crystals are normally soluble in such a solution. It frequently happens that crystalline material is rendered more intractable by the processes of replication.) Platinum, however, gave a shadowcast layer which showed little grain and was unaffected by the extraction procedure.

Thin section cutting. The blocks of agar or membranes bearing single colonies were fixed in veronal buffered $1 \%(\mathrm{w} / \mathrm{v})$ potassium permanganate solution (pH 7.2-7.4). After washing and dehydration through a series of ethanolwater mixtures, the blocks were embedded in 'Araldite' (Glauert, Rogers \& Glauert, 1956) by using standard methods.

\section{RESULTS \\ Carbon replicas}

Plate 1, fig. 1, shows a micrograph of a replica with a spore and a crystal in the field. The surface ridging on the crystal originally noted by Hannay \& Fitz-James (1955) is shown more clearly in high resolution micrographs (Pl. 1, figs. 2, 3). The ridging is clearly a feature of the surface topography. The crystals are tetragonal bi-pyramids and the periodicity measured along the unique axis of the tetragonal crystal is $290 \AA$, after due allowance has been made for the tilt of the crystal face.

The shadowing direction on the crystal in $\mathrm{Pl}$. 1, fig. 3, is such as to begin to show up detail in a direction normal to the ridging. The periodicity is $252 \AA$ (after allowing for the tilt of the face). The ratio of the two spacings is thus $0 \cdot 87$. The observed morphology of the crystals suggests an axial ratio of $0 \cdot 43$.

\section{Cell sections}

Plate 2, fig. 4, shows an early stage in spore and crystal formation. The spore wall (SW) is visible but there is no delimitation of the cortex. The crystal material $(C R Y)$ is stained darkly by the potassium permanganate fixative and is seen to be closely associated with the nuclear body of the sporangium. The outer wall of the sporangium $(\mathrm{CW})$ is clearly seen. Cells at a slightly later stage are shown in Pl. 2, figs. 5, 6. The spore cortex $(C O R)$ is now visible and the exosporium $(E)$ can be seen. At a later stage (Pl. 2, fig. 7 ) the cytoplasm of the sporangium has undergone considerable lysis and the relationships of the spore, crystal, exosporium and sporangial wall are clearly seen. The sporangial wall in Pl. 2, fig. 7, is showing signs of disintegration and this has proceeded further in $\mathrm{Pl}$. 3, figs. 8, 9, where spores, surrounded by their intact exosporia, and crystals are being released from the sporangium. There was no regularity about the position of the crystal with respect to the spore. In some cells the crystal was situated close to the spore, in others it was formed at the end of the nuclear body distal to the spore. 


\section{DISCUSSION}

Although ultra-thin sectioning techniques have been applied to sporulating cells of Bacillus cereus by several workers (Robinow, 1953; Chapman, 1956) the crystal-producing varieties have received relatively little attention. Hannay (1956) published an electron micrograph of an ultra-thin section of $B$. thuringiensis showing the crystal in situ in the sporangium and suggested that the membranous exosporium surrounding the spore of this organism may be synthesized within the bacterial cell at sporulation and is not, as has often been assumed, merely a remnant of the wall of the sporangium. This idea is supported by the findings of Chapman (1956) with B. cereus and of Young (1958) with $B$. cereus var. alesti. The present investigation has further confirmed the intracellular origin of the exosporium in $B$. cereus var. alesti.

Hannay (1956), studying stained preparations with the light microscope, found that the growth of the crystal in Bacillus thuringiensis appeared to be more closely associated with those chromatinic bodies which do not contribute to sporulation than to any stage in the development of the spore. The present work supports the view that crystal formation is closely associated with the nuclear materials of the sporangium.

Regular ridging on the surface of the crystals of Bacillus thuringiensis was noted by Hannay \& Fitz-James (1955). Manipulation of the electron beam intensity produced 'shells' derived from the outer layers of the crystal and these 'shells' showed clear ridging. Hannay \& Fitz-James were aware of the danger that a technique of this type might give rise to artifacts but were of the opinion that the periodicity reflected a structural characteristic of the crystals. This view is substantiated by the replica preparations of crystals of $B$. cereus var. alesti studied by the present authors.

By analogy with previous work on protein crystals (Wyckoff, 1948; Dawson, 1951; Dawson \& Watson, 1959) it is conceivable that the periodic ridging is related to an axial spacing along the unique axis of the tetragonal crystal, with the $252 \AA$ periodicity representing a spacing along one of the two-fold axes of the crystal. The ratio of the two spacings $(0 \cdot 87)$ is approximately twice the axial ratio deduced from morphological considerations $(0 \cdot 43)$. The value of 0.87 could, however, still be consistent with the ridges resulting from a tetragonal packing in which there are twice as many molecules casting a shadow along the 4-fold axis of the unit cell as there are along one of the twofold axes. The results thus suggest that the ridging reflects molecular packing in the crystal rather than some form of surface membrane still adhering to the crystals after rupture of the cell.

D. H. W. is indebted to Imperial Chemical Industries Ltd. for a research fellowship received during the course of this work, and J.R.N. is grateful to the Agricultural Research Council for a grant in aid of this investigation. We acknowledge gratefully the advice and encouragement received from Dr I. M. Dawson (Chemistry Department, University of Glasgow). We are also indebted to Dr C. L. Hannay for a culture of Bacillus cereus var. alesti; and to Miss E. J. Truswell and Mr G. H. Mills of the Chemistry Department and Miss M. Flanagan of the Bacteriology Department for technical assistance. 


\section{REFERENCES}

ANGus, T. A. (1954). A bacterial toxin paralysing silkworm larvae. Nature, Lond. $173,545$.

ANGus, T. A. (1956). Association of toxicity with protein-crystalline inclusions of Bacillus sotto Ishiwata. Canad. J. Microbiol. 2, 122.

Berliner, E. (1915). Über die Schlafsucht der Mehlmottenraupe (Ephestia kuhniella Zell.) und ihren Erreger Bacillus thuringiensis, n.sp. Z. angew. Ent. 2, 29.

Bradley, D. \& Williams, D. J. (1957). An electron microscope study of the spores of some species of the genus Bacillus using carbon replicas. J. gen. Microbiol. $17,75$.

Chapman, G. B. (1956). Electron microscopy of ultra-thin sections of bacteria. II. Sporulation of Bacillus megaterium and B. cereus. J. Bact. 71, 348 .

Dawson, I. M. (1951). Crystal structure of a low molecular weight protein; electron microscopy of $\beta$ lactoglobulin crystals. Nature, Lond. 168, 24.

Dawson, I. M. \& Watson, D. H. (1959). An electron microscope study of the structure of crystalline ribonuclease. J. mol. Biol. $1,30$.

Glauert, A. M., Rogers, G. E. \& Glauert, R. H. (1956). A new embedding medium for electron microscopy. Nature, Lond. 178, 803.

Hannay, C. L. (1953). Crystalline inclusions in aerobic spore forming bacteria. Nature, Lond. 172, 1004.

Hannay, C. L. (1956). Inclusions in bacteria: In Bacterial Anatomy. Symp. Soc. gen. Microbiol. 6, 318.

Hannax, C. L. \& Fitz-James, P. C. (1955). The protein crystals of Bacillus thuringiensis Berliner. Canad. J. Microbiol. 1, 694.

Heimpel, A. M. \& Angus, T. A. (1958). The taxonomy of insect pathogens related to Bacillus cereus Frankland and Frankland. Canad. J. Microbiol. 4, 531.

Mattes, O. (1927). Parasitäre Krankheiten der Mehlmottenlarven und Versuche über ihre Verwendbarkeit als biologisches Bekämpfungsmittel. Gesel. Beförd. Gesam. Naturw. Sitzber, Marburg, 62, 381.

Robinow, C. F. (1953). Spore structure as revealed by thin sections. J. Bact. 66, 300.

Steinhaus, E. A. (1954). Further observations on Bacillus thuringiensis Berliner and other spore forming bacteria. Hilgardia, 23, 1.

Toumanoff, C. (1955). Au sujet des souches cristallophores entomophytes de Bacillus cereus. Observations sur leurs inclusions cristallines. Ann. Inst. Pasteur, 89, 644.

Toumanoff, C. \& VAgo, C. (1951). L'agent pathogène de la flacherie des vers à soie endémique dans la région des Cévennes; Bacillus cereus var. alesti var. nov. C.R. Acad. Sci. Paris, 233, 1504.

Vankova, J. (1957). Study of the effect of Bacillus thuringiensis on insects. Folia Biol. 3, 175.

Wyckoff, R. W. G. (1948). Electron microscopy of macromolecular crystals. Acta crystallographica, 1, 292.

Young, E. (1958). Chemical and morphological changes during sporulation in variants of Bacillus cereus. Ph.D. thesis, University of Western Ontario.

\section{EXPLANATION OF PLATES}

\section{Plate 1}

Electron micrographs of platinum shadowed carbon replicas of Bacillus cereus var. alesti.

Fig. 1. Spore and crystal. $\times 27,000$.

Fig. 2. Crystal showing periodic ridging in one direction. $\times 113,000$

Fig. 3. Crystal showing periodic ridging in two perpendicular directions. $\times 108,000$. 


\section{Journal of General Microbiology, Vol. 22, No. 3}

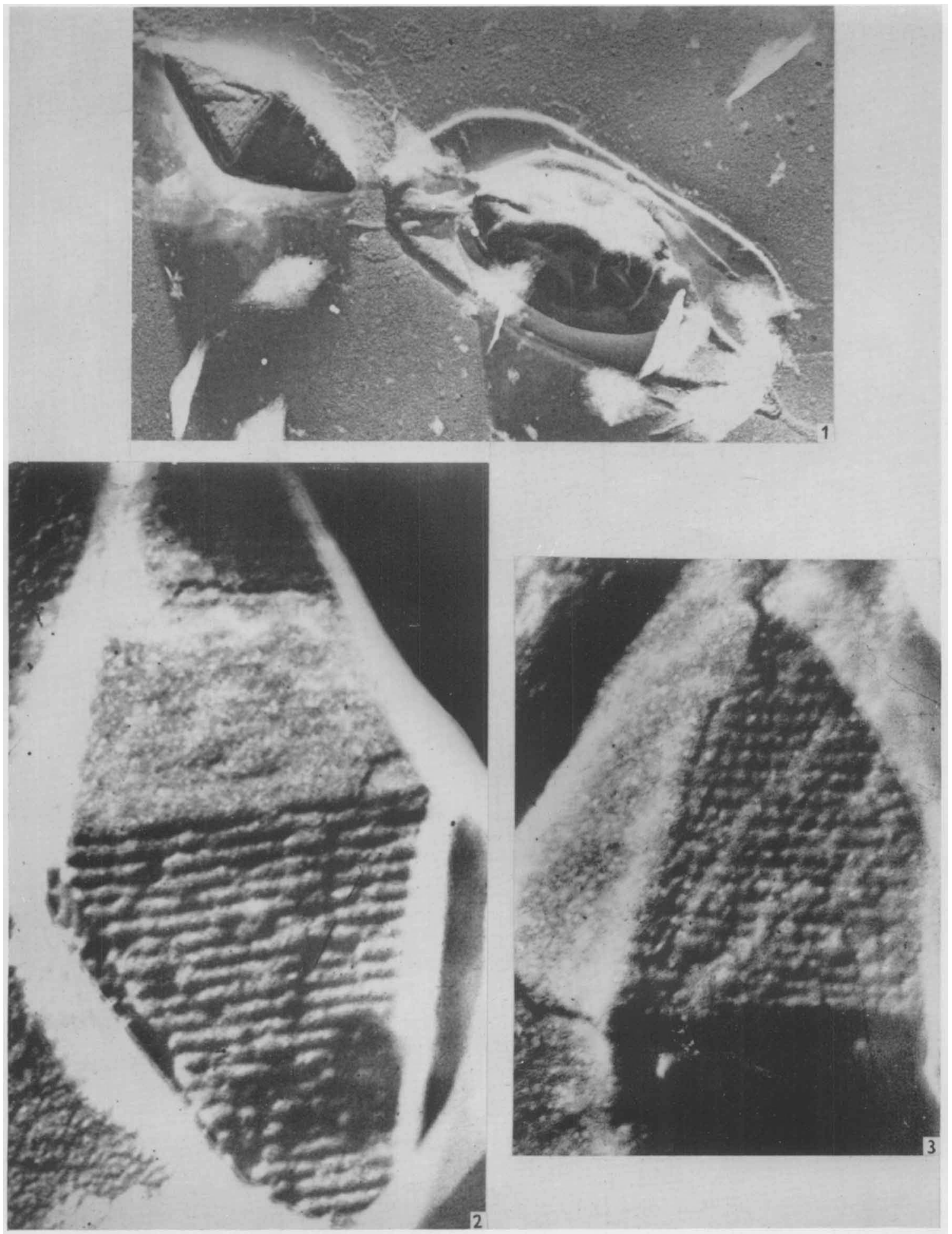

J. R. Norkis and D. H. Watson-Electron microscopy of Bacillus cereus. Plate 1 
Journal of General Microbiology, Vol. 22, No. 3

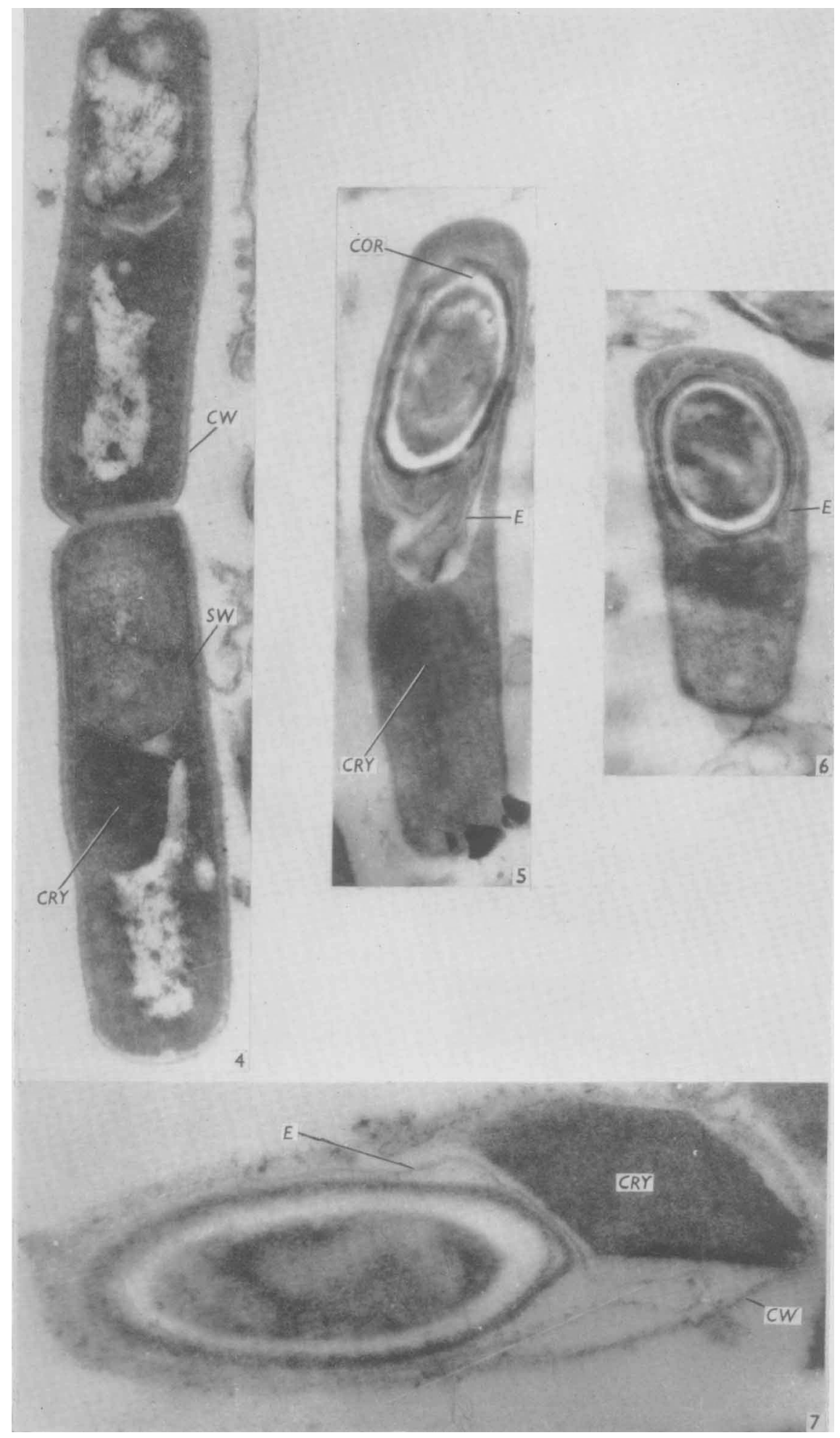

J. R. Norris and D. H. Watson-Electron microscopy of Bacillus cereus. Plate 2 
Journal of General Microbiology, Vol. 22, No. 3

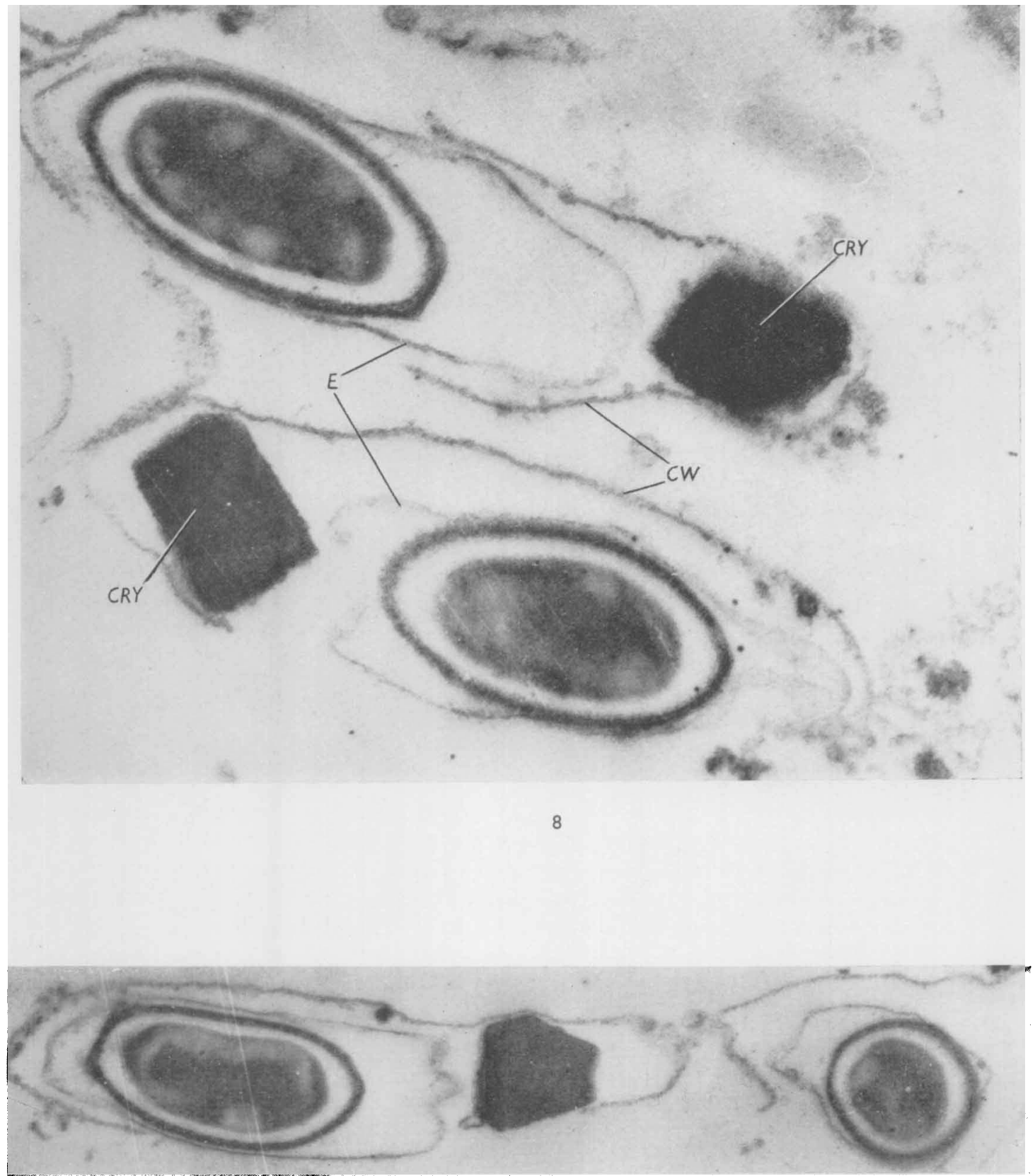

9

J. R. Norris and D. H. Watson-Electron microscopy of Bacllles cereus. Plate 3 
Plate 2

Electron micrographs of ultra-thin sections of cells of Bacillus cereus var. alesti fixed with buffered potassium permanganate and embedded in Araldite. $S W=$ spore wall; $C W=$ sporangium wall; $C R Y=$ protein crystal; $C O R=$ spore cortex; $E=$ exosporium.

Fig. 4. Early stage in spore and crystal formation. $\times 37,700$.

Figs. 5, 6. Slightly later stages. $\times 28,600$ and $\times 29,200$ respectively.

Fig. 7. Spore and crystal formation complete. $\times 48,400$.

\section{Plate 3}

Electron micrographs of ultra-thin sections of old cells of Bacillus cereus var. alesti fixed with buffered potassium permanganate and embedded in Araldite. Release of spores and crystals by disintegration of the vegetative cell wall remnants.

Fig. 8. $\times 49,000$

Fig. 9. $\times 38,000$.

(Received 15 December 1959) 